\title{
How Can We Define 'Innovation'?
}

\author{
Daniel Forbes (University of Minnesota)
}

KEYWORDS: Innovation, Management, Organization, Product Development, Strategy, Technology Commercialization, Innovators.

Innovation is a kind of Holy Grail in the world today. Companies strive for it, consumers often reward it, and policy-makers say we need more of it.

But many people still find themselves asking, "What exactly is innovation?" I hear this question a lot in my work as a business school professor. Here l'll address three common questions about innovation: What is it? Why is it important? And how does it relate to entrepreneurship?

\section{What is innovation?}

It's very reasonable for people to ask this question. Many scholars, consultants and other experts remain a little bewildered by innovation. Consider how two leading economists characterize it:

"Innovation is essentially a two-sided or coupling activity ... On the one hand, it involves the recognition of a need or more precisely, in economic terms, a potential market for a new product or process. On the other hand, it involves technical knowledge, which may be generally available, but may also often include new scientific and technical knowledge, the result of original research activity. Experimental development and design, trial production and marketing involve a process of matching the technical possibilities and the market. The professionalization of industrial $R \& D$ represents an institutional response to the complex problem of organizing this matching, but it remains a groping, searching, uncertain process." (Freeman \& Soete, 1997; p. 200).

So there you have it: some confusion and uncertainty is inherent in innovation. It's also clear that innovation is a process, but as we will soon see the term can also refer to the outcome of that process, such as a new product or service.

Now let's consider the view from the field of management, which is my own field. As a scholarly field, management is related to economics, but it tends to focus more on what happens inside of organizations as people try to manage them. Accordingly, many management scholars have defined innovation in ways that emphasize the organizational adoption of new ideas (Crossan \& Apaydin, 2010). For example, Damanpour (1996) defined innovation as "a means of changing an organization" and noted that the relevant changes may take several forms, including "new products or services, new process technologies, new organizational structures or administrative systems, or new plans or programs pertaining to organization members" (p. 694). Amabile (1988) took a similar view when she defined innovation as "the successful implementation of creative ideas within an organization," noting further that creative ideas were those that were "novel and useful" (p. 126). Sometimes management scholars distinguish between "product innovation," which refers to developing a new product or service, and "process innovation," which refers to developing a new way of doing things within the firm.

Most people find it easier to understand product innovations than process innovations. To get at process innovation, it can be helpful to step back and take the view that all organizations are built of routines, or recurrent patterns of collective behavior (Becker, 2004). Organizations undertake process innovations when they change their routines. Think about postal delivery as a set of interrelated routines. What happens when you put a handwritten letter in the mailbox? The letter gets to its destination thanks to a carefully connected set of organizational routines, which in turn represent the integration of various organizational resources: The letter gets picked up by a truck; it gets driven to a central place, where it gets sorted and routed; and so on. This is a very long-established set of routines, of course, although we still rely on them for some purposes. Some organizations (like FedEx and the U.S. Postal Service) still work on improving this basic set of routines. Each time they do so, it represents a process 
innovation.

Another distinction we can make among innovations is the distinction between "incremental" and "radical" innovation. Incremental innovations are refinements of existing routines or products. For example, the introduction of Zip Codes in 1963 was an incremental innovation - it made mail delivery more efficient, but it didn't materially change the overall process. On the other hand, in the past 50 years, entirely new industries have arisen based on completely different sets of routines that enable us to send faxes, emails and texts all things that improve the broader process of longdistance communication that underlies "mail delivery." These more substantial innovations are sometimes called radical innovations. As Mary Benner (forthcoming) explains, radical innovations "entail a shift to a new base of knowledge or 'science' underlying the products in an industry, along with an improved price/performance frontier for products enabled by the new technology."

In my mind, the term innovation applies best to cases in which a firm makes a change to the "standard recipe" for how an organization of its type is supposed to do things. The economists I quoted earlier share this view: Technically, they write, an innovation "is accomplished only with the first commercial transaction involving the new product, process system or device," but they go on to acknowledge that "the word is also used to describe the whole process" (p. 6). If an organization imitates a change that was first developed elsewhere (e.g., by another firm in its industry), that can be seen as the diffusion of an earlier innovation. Diffusion is also an important change process: Adopting innovations that others have shown to work well is a powerful way for organizations to improve what they're doing. But that's a different process from the one involved in developing an innovation from scratch.

When someone offers you a definition of innovation, ask them for an example of something that is not innovation. This is important, because people sometimes get carried away and equate innovation with almost anything (or any good thing) an organization does. But that's unlikely to give us a useful definition of anything. If we define innovation as a change in routines, then executing a well-established routine - as FedEx does, for example, when they deliver your package on time in the usual way - is not innovative. Is it bad for firms to do things that aren't innovative? No, not at all. In fact, it's important for most firms to be able to execute certain routines well and consistently. In many markets, such as air travel, customers value the safety and efficiency that reliable routines can deliver. Thus, even though innovation is important for reasons I'm about to explain, let's recognize that some work can be "not innovative" and still important.

\section{Why is innovation important?}

Innovation is important because organizations must move forward in a world that is constantly changing. Some of those changes can pose threats to an organization's well-being, while others represent opportunities for the organization to become even more effective. Innovation provides a way for organizations to respond to threats and exploit opportunities as they materialize over time.

For example, consider the invention of the "Swatch" wristwatch as it has been described in a Harvard Business School case (Moon, 2004). Early in the 20th century, watches were a kind of jewelry - a special product that was hard to make and expensive to buy, owing to both the process and the components that went into its manufacture. But that changed with a series of technologically based innovations, and by the 1970 s the watch industry was dominated by large-scale, low-cost manufacturers. Swiss watchmakers, who had historically excelled at making luxury watches, found themselves especially vulnerable to the introduction of these technologically based innovations. In 1983, however, one Swiss firm invented the Swatch: a colorful, moderately priced watch that served as a playful fashion accessory. The Swatch opened up a new segment of the watch industry by redefining the product and its markets in some key ways. Ten years later, the Swatch was the best-selling watch in industry history, and the firm that invented it (later renamed the "Swatch Group") went on to prosper for years afterwards.

As the Swatch example illustrates, innovation can represent both a threat and opportunity. Moreover, a single innovation can be an opportunity for some firms and a threat to others at the same time. In the case of Swatch, it's easy to see in retrospect why the effort to introduce a new watch was worthwhile. But in the early stages of an innovative process, it can be very hard to make an economic case for investments in innovation. This is especially true with radical innovation in large firms. As I noted earlier, managers devote a lot of attention to managing existing processes. To the extent 
they are willing to invest in innovation, they tend to favor incremental innovations, because it's generally easier to make an economic case for improvements to a firm's existing products and markets. It is harder to make an economic case for radical innovations, which require firms to engage with less-familiar technologies and customers and are often more uncertain (Benner \& Tushman, 2003). Sometimes, as a result, radical innovations are undertaken in small new ventures, where entrepreneurs may be more strongly motivated by non-economic goals, such as a desire to change the world. Nevertheless, it is also possible for large firms to introduce radical innovations, and some management tools can help them do so (e.g., Nadler \& Tushman, 1997).

\section{How does innovation relate to entrepreneurship?}

The relationship between innovation and entrepreneurship is close enough that the two terms are sometimes used interchangeably. But there are differences in how each term tends to be used.

Entrepreneurship, according to one of the most commonly used scholarly definitions, refers to the "discovery and exploitation of profitable opportunities" (Shane \& Venkataraman, 2000; p. 217). With this definition in mind, it is easy to see a clear connection between entrepreneurship and innovation as defined above in that private sector firms are interested in those "changes in routines" that enable them to earn more profits. By this view, too, we can imagine entrepreneurship occurring in a wide range of for-profit firms: in small, independent new ventures, for example, as well as in larger, more established firms, in which case people may call it "corporate entrepreneurship" (Zahra, 1996).

At the same time, people tend to talk about "innovation" when they're talking about changes within an organization (or an industry) that is already up and running at some significant scale. For example, in the book, The Innovation Journey (1999), Andy Van de Ven and his colleagues present insights drawn from their indepth study of innovative initiatives undertaken by the $3 \mathrm{M}$ Corporation. It is less common for people to talk about "organizational innovation" in a very new firm, because those firms are still establishing their own routines (Aldrich \& Ruef, 2006). However, those same new firms might be engaged in innovation in the broader sense that they are developing sets of routines that represent a new way of operating within a certain industry.

Meanwhile, others have defined "entrepreneurship" to mean the creation of new organizations (Gartner, 1989). This is a different meaning of entrepreneurship, and under this meaning it is possible to talk about "nonprofit entrepreneurship" (Cordes et al., 2004), a term that would make no sense under the prior definition. It's worth noting, however, that many new ventures (e.g., most dry cleaners) are not especially innovative - i.e., their routines are virtually identical to those of many other firms in their industries. In addition, the "organization creation" definition of entrepreneurship is further limited by the fact that established firms can also create new organizational units inside or outside of their existing boundaries; in fact, they often do so in an effort to facilitate innovation (e.g., Christensen \& Overdorf, 2000).

In summary, entrepreneurship and innovation overlap significantly and the distinctions between them are not airtight. But there are some differences in how these terms are commonly used, and being attentive to those differences can help you discern what kinds of activities people are referring to.

\section{Conclusion}

Even as consultants, authors and others have stepped forward to offer elaborate innovation-related insights to a world hungry for such knowledge, I have found that many people simply want a clearer sense of what innovation means. In this article l've tried to provide a short introduction to innovation by drawing on what management scholars have had to say about it. For a more complete picture, it may be useful to explore what's been learned about innovation in other fields besides management, such as marketing (e.g., Tellis, 2013) or product design (e.g., Ulrich \& Eppinger, 2016) as well as economics (e.g., Freeman \& Soete, 1997).

\section{References}

Aldrich, H. \& Ruef, M. 2006. Organizations evolving. (2nd ed.) London: Sage.

Amabile, T. 1988. A model of creativity and innovation in organizations. Research in Organizational Behavior, 10: 123-167.

Becker, M. 2004. Organizational routines: A review of 
the literature. Industrial \& Corporate Change, 13: 643-677.

Benner, M. Forthcoming. "Innovation, management practices, and productivity." In E. Grifell-Tatje, C.A. Knox-Lovell \& R.C. Sickles (Eds.) Oxford Handbook of Productivity Analysis, Chapter 11. Oxford, UK: Oxford U. Press.

Benner, M. \& Tushman, M. 2003. Exploitation, exploration and process management: The productivity dilemma revisited. Academy of Management Review, 28: 238-256.

Christensen \& Overdorf, 2000. Meeting the challenge of disruptive change. Harvard Business Review, MarchApril.

Cordes, J., Steuerle, C.E. \& Twombly, E. 2004. "Dimensions of nonprofit entrepreneurship: An exploratory essay." In D. Holtz-Eakin and H.S. Rosen (Eds.) Public policy and the economics of entrepreneurship, pp. 115-151. Cambridge, MA: MIT Press.

Crossan, M. \& Apaydin, M. 2000. A multi-dimensional framework of organizational innovation: A systematic review of the literature. Journal of Management Studies, $1154-1191$

Damanpour, F. 1996. Organizational complexity and innovation: Developing and testing multiple contingency models. Management Science, 42: 693-71

Freeman, C. \& Soete, L. 1997. The economics of industrial innovation (3rd ed.) Cambridge, MA: MIT Press.

Gartner, W. 1989. 'Who is an entrepreneur?' is the wrong question. Entrepreneurship Theory \& Practice, 47-68.

Moon, Y. 2004. The birth of the Swatch. Harvard Business School Case \#9-504-096. Boston, MA: HBS Publishing.

Nadler, D. \& Tushman, M. 1997. Competing by design: The power of organizational architecture. Oxford, UK: Oxford University Press.

Shane, S. \& Venkataraman, S. 2000. The promise of entrepreneurship as a field of research. Academy of
Management Review, 25: 217-226.

Tellis, G. 2013. Unrelenting innovation. How to create a culture for market dominance. San Francisco: JosseyBass.

Ulrich, K.T. \& Eppinger, S.D. 2016. Product design and development. (6th ed.) McGraw-Hill/Irwin.

Van de Ven, A.H., Polley, D.E., Garud, R. \& Venkataraman, S. 1999. The innovation journey. Oxford University Press.

Zahra, S. 1996. Governance, ownership and corporate entrepreneurship. Academy of Management Journal, 39: 1713-1735. 